\title{
Whitening effect of Brazilin in B16F10 cells
}

Joong Hyun Shim

Faculty of Cosmetics and Beauty Biotechnology, Semyung University, Jecheon-si, Chungcheongbuk-do, Korea

Corresponding author: Joong Hyun

Shim, Faculty of Cosmetics and Beauty

Biotechnology, Semyung University, 65

Semyung-ro, Jecheon-si, Chungchengbuk-

do 27136 , Korea

Tel.: +82436491615

Fax: +82436491730

Email: jhshim@semyung.ac.kr

Received April 4, 2019

Revised May 31, 2019

Accepted August 6, 2019

Published September 30, 2019

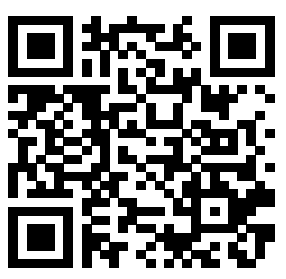

\begin{abstract}
Purpose: This study aimed to identify the whitening effect of brazilin on the B16F10 cell line. Methods: I measured the cell viability, mRNA expression, tyrosinase activity inhibition assay, and melanin contents assay from B16F10 cells. Also, I elucidated the effects of brazilin on tyrosinase-related protein 1 (TYRP1)/TYRP2/ tyrosinase $(T Y R) /$ microphthalmia-associated transcription factor (MITF) mRNA expression, and melanin production. Results: Quantitative real-time RT-PCR showed that brazilin decreased the mRNA level of TYRP1/TYRP2/TYR/MITF and melanin production compared with that of the MSH-treated B16F10 cells. The tyrosinase activity inhibition assay revealed that brazilin decreased melanin production in B16F10 cells. Conclusion: These data show that brazilin increases whitening effects in B16F10 cells and thus brazilin is a potent ingredient for skin whitening. Future studies based on these results can determine the potential uses of brazilin in cosmetics, health care, food, or medicine.
\end{abstract}

Keywords: Brazilin, Whitening, Melanin, TYR, MITF

\section{Introduction}

피부노화의 대표적인 원인인 외인성 노화는 자외선 (Ultraviolet, UV)에 의한 노화라고 할 수 있다(Chung et al., 2002; Gilchrest, 1996). 자외선은 200-400 nm 파장대의 빛으 로 태양에서 오는 광선의 약 $5 \%$ 를 차지할 정도로 적은 양이지만 적외선이나 가시광선과는 달리 피부노화에 직접적인 영향을 미 친다고 알려져 있다(Gonzalez et al., 2008). 자외선은 파장대에 따라 UVA (320-400 nm), UVB (290-320 nm), 그리고 UVC (200-290 nm)로 구분된다(Matts, 2006). 오존층에서 대부분의 $\mathrm{UVC}$ 는 흡수가 되고, 실제 지구 표면에 도달하여 피부노화에 영향 을 미치는 자외선은 UVA와 UVB이다. 많은 양의 자외선에 노출 되거나 적은 양이라도 장기간 빈번하게 자외선을 받게 되면 색소 침착, 홍반 등의 피부질환과 깊은 주름이 생기거나 피부가 거칠어 지는 피부노화가 유발된다(Bickers et al., 2006).

피부색은 혈관 속에 함유된 혈액 내 헤모글로빈과 표피에 존재 하는 멜라닌 색소(melanin), 피하조직에 분포하는 $\beta$-카로틴 등에
의해 결정된다. 그 중에서도 멜라닌 색소의 분포와 양에 의해 외 관상의 피부색이 주로 결정된다. 멜라닌은 자외선을 받은 멜라닌 형성세포(melanocyte)의 멜라닌합성반응 과정(melanogenesis) 을 통해 생성되고, 피부색을 어둡게 변화시켜 자외선으로부터 피 부를 보호하는 기능을 한다. 멜라닌에는 적갈색의 수용성 중합체 인 피오멜라닌(pheomelanin)과 흑색의 불용성 중합체인 유멜라 닌(eumelanin)으로 구성되어 있다(Yoon et al., 2013). 멜라닌 합성은 L-tyrosine이라는 아미노산을 기질로 하여 tyrosinase (TYR)를 주효소로 하고 tyrosinase related protein-1 (TYRP1), TYRP2에 의해 3,4-dihydroxyphenylalanine (L-DOPA)를 거 쳐 DOPA quinone으로 산화된 후 복잡한 기전을 거쳐 최종적으로 피오멜라닌과 유멜라닌이 만들어 진다. 이 중 TYR 효소는 멜라닌 생성반응을 조절하는 핵심 효소로, 대표적인 미백 소재인 코직산, 알부틴(arbutin), 닥나무추출물, 감초추출물 등은 TYR 효소의 활 성 억제를 타겟으로 하고 있다(Baek et al., 2009; Kim et al., 2005). 특별히 알부틴은 멜라닌의 전구체인 L-tyrosine과 경쟁 적으로 작용하여 TYR 효소의 활성을 저해하는 역할을 하며, 코직 
산은 tyrosinase의 활성부위에 결합하는 구리 2 가이온 $(\mathrm{Cu} 2+)$ 를 chelating하여 멜라닌의 전구물질인 L-DOPA와 DOPA quinone 이 생성되는 것을 억제한다고 알려져 있다. 알부틴과 코직산은 강 력한 미백효능이 있지만 피부자극과 같은 안전성 문제 등의 일부 부작용이 있어 천연유래 신소재 개발 등 신규 효능물질 발굴에 많 은 연구가 진행되고 있다(Han et al., 2014; Kim et al., 2015).

브라질린(Brazilin; 7, 11b-dihydrobenz[b]indeno[1,2-d] pyran-3,6a,9,10 (6H)-tetrol)은 말레이시아, 인도, 중국 남부 지역 등의 열대 아시아에 분포하는 콩과 식물인 소목(Caesalpinia sappan L.)의 지표물질로 알려져 있다. 브라질린은 천연색소, 식 품 첨가물 또는 산 및 알칼리 지시약 등으로 널리 사용되어져 왔 다(Puchtler et al., 1986). 최근의 연구결과에서는 고혈압, 향균 작용, 월경폐색, 어혈에 의한 타박손상, 혈당저하, 항산화, 항염 작용, 항노화 등의 다양한 생리학적 효능이 보고된 바 있다(Moon et al., 1992; Hwang et al., 1998; Bae et al., 2005; Shim, 2016; Hwang et al., 2018; Shim, 2019).

브라질린이 피부미백 개선에 효능이 있는지에 대한 연구는 전 무한 실정이다. 본 연구에서는 브라질린의 미백 효능과 관련되 어 B16F10 세포의 표지인자인 TYRP1과 TYRP2, TYR, MITF 등의 유전자 발현에 미치는 영향을 확인해 보고, $\alpha$-melanocyte stimulating hormone $(\alpha-\mathrm{MSH})$ 에 의해 증가된 멜라닌의 생산량 이 브라질린에 의해 감소되는지 입증하고자 한다. 이를 통해 브라 질린의 향후 미백 화장품 및 바이오 소재로서의 가능성을 제시하 고자 한다

\section{Materials and Methods}

\section{1. 실험재료 및 세포배양}

마우스 유래 흑색종 세포인 B16F10 세포주는 한국세포주은 행(Korean Cell Line Bank, Korea)에서 구매하여 사용하였 으며, 세포배양을 위해 Dulbeccos modified Eagles medium (DMEM, Welgene, Korea)에 10\%의 fetal bovine serum (FBS, Equitech-Bio, USA)와 $1 \%$ 의 penicillin/streptomycin (Thermo Fisher Scientific, USA)을 첨가하여 $5 \% \mathrm{CO}_{2}, 37^{\circ} \mathrm{C}, 100 \%$ 인큐 베이터에서 배양하였다.

\section{2. 세포 생존율 측정}

세포 생존율은 $\mathrm{CCK}-8$ (cell counting kit-8, Abbkine, China) 분석법을 이용하였다. $\mathrm{B} 16 \mathrm{~F} 10$ 세포를 조직배양접시에 접 종한 후 브라질린(ChemFaces, China)을 농도 별로 희석하여 처 리하였다. 브라질린을 농도 별로 처리한 B $16 \mathrm{~F} 10$ 세포를 $24 \mathrm{~h}$ 배 양한 후 CCK-8 시약을 첨가하여 $1 \mathrm{~h}$ 동안 $5 \% \mathrm{CO}_{2}, 37^{\circ} \mathrm{C}$ 인큐 베이터에서 배양하였다. $450 \mathrm{~nm}$ 에서 흡광도를 측정하기 위해 ELISA reader (BioTek, USA)를 사용하였으며, 세포를 첨가하지 않은 배지만 넣은 대조군의 흡광도를 기준으로 세포 생존율을 산 출하였다.

\section{Mushroom tyrosinase activity 측정}

Mushroom Tyrosinase (EC 1.14.18.1, Sigma, USA)의 농도 가 276 units $/ \mathrm{mL}$ 가 되도록 1/15M phosphate buffer $(\mathrm{pH}$ 6.8) 에 녹여 냉동실에 동결 보관하고, 사용 시 빙상에서 녹여 사용하 였다. tyrosine (Sigma)은 차광 병에서 deionized water (Sigma) 에 녹여서 사용하였으며, 본 용액은 사용 직전에 제작하여 사용하 였다.

Mushroom tyrosinase (13.8 units/ml) $150 \mu \mathrm{L}, 1 / 15 \mathrm{M}$ phosphate buffer를 넣은 후, 상온에서 $5 \mathrm{~min}$ 간 pre-incubation 시켰다. 여기에 tyrosine을 넣은 후 $5 \mathrm{~min}$ 간 반응시킨 후 $475 \mathrm{~nm}$ 에서 흡광도를 측정하였다. 각 실험군은 모두 독립적으로 3 번 반 복 실험하였고, 아래의 수식으로 소재의 효소 저해율(\%)을 산출하 였다.

저해율 $=[1-($ 시료첨가군의 흡광도/무첨가군의 흡광도 $)] \times 100$

\section{RNA 추출 및 실시간 유전자 중합효소 연쇄반응(real-time RT-PCR)}

Thermo Fisher Scientific사의 TRIzol Reagent (USA)를 사용 하여 total RNA를 추출하였다. 추출한 total RNA로부터 $\mathrm{cDNA}$ 의 합성은 TOPscript one step RT-PCR kit (Enzynomics, Korea) 를 사용하여 합성하였으며, B16F10 세포의 표지인자의 발현 을 비교 측정하기 위하여 StepOnePlus realtime PCR machine (Applied Biosystems, USA)을 사용하여 real-time RT-PCR 을 진행하였다. 실험에 사용된 특정 Taqman Gene expression $\operatorname{assay}^{\circledR}$ 는 Table 1 에 표기하였다.

Table 1. Gene name and assay ID number in real-time RT-PCR analysis

\begin{tabular}{lll}
\hline Symbol & \multicolumn{1}{c}{ Gene name } & Assay ID \\
TYRP1 & Tyrosinase-related protein 1 & Mm00453201_m1 \\
TYRP2 & Tyrosinase-related protein 2 & Mm01225584_m1 \\
TYR & Tyrosinase & Mm00495817_m1 \\
MITF & Microphthalmia-associated transcription factor & Mm00434954_m1 \\
GAPDH & Glyceraldehyde-3-phosphate dehydrogenase & Mm99999915_g1 \\
\hline
\end{tabular}




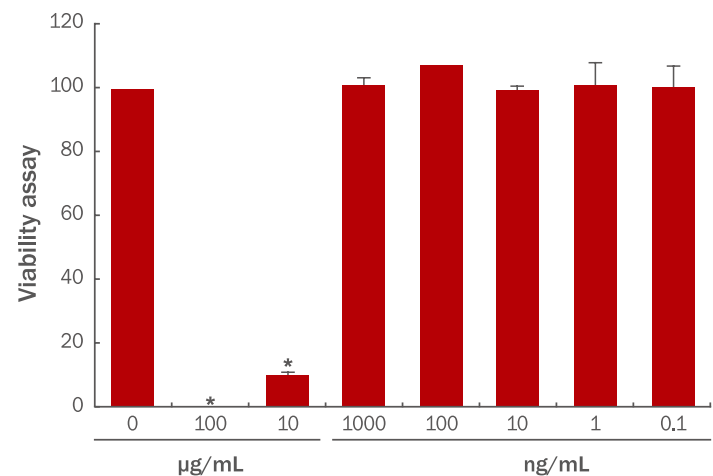

Figure 1. Cytotoxicity aspects of brazilin on B16F10 cell line. B16F10 cells $\left(2 \times 10^{3}\right.$ cells) were seeded in 96-well plate and treated indicated concentration of brazilin for $24 \mathrm{~h}$. Cell viability was measured by CCK- 8 assay. The results are presented as the mean \pm standard deviation of the percentage of control optical density in triplicate. ${ }^{*}$ means compared to control $\left({ }^{*} p<0.05\right)$.

\section{Melanin 생성량 측정}

Melanin 생성량 측정은 Hosoi의 방법을 일부 변경하여 사용 하였다(Hosoi et al., 1985). B16F10 세포를 24 well plate에 1 $\times 10^{5}$ cells/well 농도로 접종하였다. $24 \mathrm{~h}$ 동안 안정화 시킨 후에 $\alpha-\mathrm{MSH}$ (200 nM, Sigma)와 브라질린을 농도 별로 처리하였다. $72 \mathrm{~h}$ 배양 후 배지를 제거한 다음 phosphate-buffered saline (PBS, Welgene)로 3차례 washing 한 후, $1 \mathrm{~N} \mathrm{NaOH}$ (Sigma) 용액을 $100 \mu \mathrm{L}$ 를 첨가하여 $60^{\circ} \mathrm{C}$ 에서 $2 \mathrm{~h}$ 동안 melanin을 용해 시킨 후에 $405 \mathrm{~nm}$ 의 파장에서 흡광도를 측정하였다. 양성대조군 은 $100 \mu \mathrm{g} / \mathrm{mL}$ 의 arbutin (Sigma)을 사용하였다. Melanin 생성 억제는 $\alpha-\mathrm{MSH}$ 처리군에 대한 생성량을 퍼센트로 표시하여 평균 치로 나타내었다. 실험은 독립적으로 3 번 반복하였다

\section{6. 통계분석}

통계처리는 Students $t$-test법을 이용하여 유의 수준을 0.05 $(p<0.05)$ 로 하여 검정하였다.

\section{Results \& Discussion}

\section{1. 브라질린 농도별 B16F10 세포의 생존율 분석}

$\mathrm{B} 16 \mathrm{~F} 10$ 세포에 대한 브라질린의 세포독성을 확인하기 위하여 $\mathrm{CCK}-8$ assay를 실시하였다. 대조군은 시료를 처리하지 않았고 브라질린은 $0.1,1,10,100,1000 \mathrm{ng} / \mathrm{mL}, 10,100 \mu \mathrm{g} / \mathrm{mL}$ 의 농도로 처리하여 세포생존율을 측정하였다(Figure 1). $10 \mu \mathrm{g} / \mathrm{mL}$ 이상의 농도를 처리할 때 $\mathrm{B} 16 \mathrm{~F} 10$ 세포의 생존율이 유의성있게 감 소하였다. $1000 \mathrm{ng} / \mathrm{mL}$ 의 농도 이하로 처리시에는 $\mathrm{B} 16 \mathrm{~F} 10$ 세포 의 생존율이 대조군과 비교하여 유사함을 확인하여 본 실험에서는

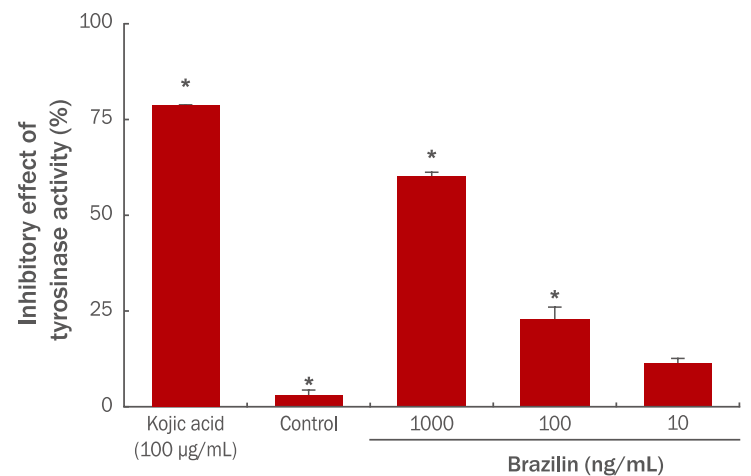

Figure 2. Tyrosinase activity inhibition of brazilin.

The results were expressed as the average of triplicate samples. "means compared to control ( $\left.{ }^{*} p<0.05\right)$.

$10,100,1000 \mathrm{ng} / \mathrm{mL}$ 의 브라질린을 처리하여 미백 효능 실험을 진행하였다.

\section{2. 브라질린에 의한 Tyrosinase 효소 저해 활성 효과}

Tyrosinase 효소는 아미노산인 L-tyrosine을 기질로 하여 $\mathrm{L}-\mathrm{DOPA}$ 를 생성하고, L-DOPA는 tyrosinase 효소에 의하여 dopaquinone을 걸쳐 최종적으로 멜라닌이 형성된다. Tyrosinase 효소는 멜라닌합성반응을 조절하는 효소로, 대표적인 미백 화 장품 원료인 알부틴, kojic acid, 감초추출물, 닥나무추출물 등 은 tyrosinase 활성을 억제하는 소재로 개발되어 사용되고 있다 (Baek et al., 2009; Kim et al., 2005). 본 실험에서 브라질린의 tyrosinase 효소 저해 활성을 평가하기 위하여 kojic acid를 양성 대조군으로 사용하고 브라질린을 각각 $10,100,1000 \mathrm{ng} / \mathrm{mL}$ 의 농도로 처리하여 tyrosinase 효소 활성을 측정한 결과, 브라질린 의 농도의존적으로 tyrosinase 효소의 활성을 저해함을 확인할 수 있었다(Figure 2). 브라질린 $100,1000 \mathrm{ng} / \mathrm{mL}$ 에서 각각 22.9 , $59.9 \%$ 의 tyrosinase 저해 효능을 나타내어 우수한 미백효과가 있 음을 확인하였다.

\section{3. $\alpha-\mathrm{MSH}$ 와 브라질린 처리에 따른 B16F10 세포의 mRNA 발현}

자외선은 직접적으로 멜라닌형성세포를 자극하여 멜라닌을 합 성하지 않고, 여러 단계의 신호전달을 거쳐 멜라닌을 생성하게 한 다. 자외선은 표피층에 존재하는 각질형성세포를 자극하여 멜라 닌형성세포 자극 호르몬인 $\alpha$-melanocyte stimulating hormone $(\alpha-\mathrm{MSH})$ 의 생성을 유발하여, 각질형성세포 외부로 분비시키 고, 분비된 $\alpha-\mathrm{MSH}$ 는 멜라닌형성세포의 수용체인 melanocortin 1 receptor $(\mathrm{MC1R})$ 에 결합하여 멜라닌 합성에 관련된 신호전달 을 통해 멜라닌 생성을 유발한다(Yoon et al., 2013). 본 실험에 서는 B16F10 세포의 멜라닌 생성을 유발하기 위하여 $200 \mathrm{nM}$ 의 $\alpha-\mathrm{MSH}$ 를 처리하여 $\mathrm{B} 16 \mathrm{~F} 10$ 세포의 흑화를 유도하였다. 또한 브 

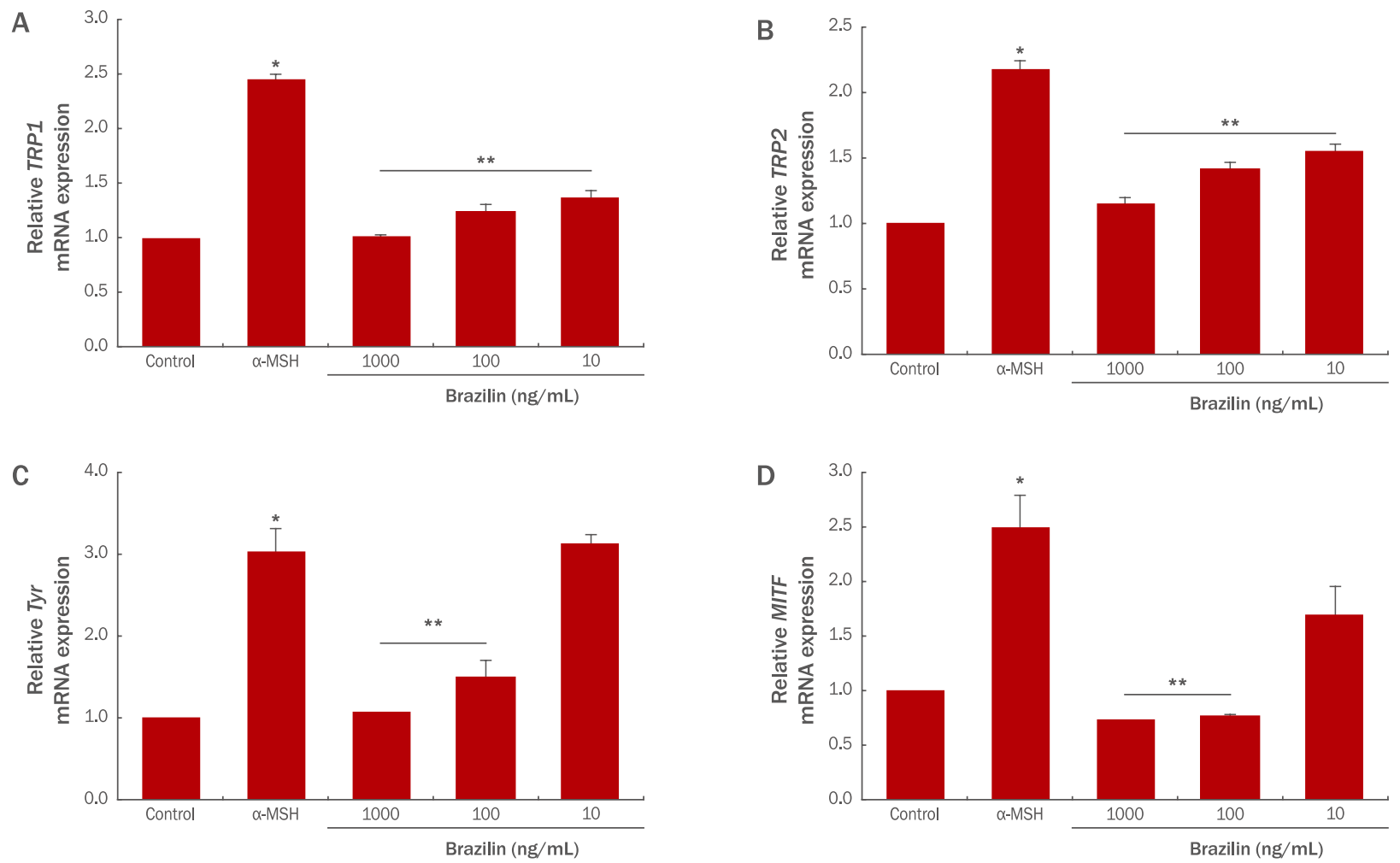

Figure 3. Characterization of brazilin treatment on $\alpha-M S H-t r e a t e d ~ B 16 F 10$ cells.

Real-time RT-PCR analysis of the melanocyte markers, TRP1 (A), TRP2 (B), Tyr (C) and MITF (D). Values represent the mean \pm standard deviation of three independent experiments. " means compared to control, ${ }^{* *}$ means compared to $\alpha-\mathrm{MSH}$-treated condition ( ${ }^{*}$, ${ }^{* *} p<0.05$ ). TRP1, tyrosinase-related protein 1; TRP2, tyrosinase-related protein 2; Tyr, tyrosinase; MITF, microphthalmia-associated transcription factor; $\alpha-\mathrm{MSH}, \alpha$-melanocyte-stimulating hormone.

라질린을 처리하여 $\mathrm{B} 16 \mathrm{~F} 10$ 세포가 $\alpha-\mathrm{MSH}$ 처리에 의해 발현하 는 표지인자인 TRP1, TRP2, TYR, MITF의 발현양을 실시간 유 전자 중합효소 연쇄반응을 통하여 확인하였다. $\alpha-\mathrm{MSH}$ 처리에 의해 $\mathrm{B} 16 \mathrm{~F} 10$ 세포는 TRP1, TRP2, TYR, MITF과 같은 멜라닌 형성세포의 표지인자의 발현이 증가한다. $\mathrm{B} 16 \mathrm{~F} 10$ 세포에 브라질 린을 처리하고 실시간 유전자 중합효소 연쇄반응을 통하여 표지인 자 발현을 확인한 결과, $\alpha-\mathrm{MSH}$ 처리군 대비 $1000 \mathrm{ng} / \mathrm{mL}$ 의 브 라질린을 처리한 실험군에서 $T R P 1, T R P 2, T Y R, M I T F$ 의 발현 이 각각 $59,47,65,71 \%$ 감소하는 효과를 보였다(Figure 3 ).

\section{4. 브라질린의 멜라닌 생성률 저하 효과}

브라질린을 처리하여 멜라닌형성에 필수적인 표지인자의 $\mathrm{mRNA}$ 발현량이 감소됨을 확인한 이후, $\mathrm{B} 16 \mathrm{~F} 10$ 세포에서 멜라 닌 생성이 감소되는지를 알아보기 위해 멜라닌 생성률을 확인하 였다(Figure 4). 브라질린을 각각 $10,100,1000 \mathrm{ng} / \mathrm{mL}$ 농도로 처리한 $\mathrm{B} 16 \mathrm{~F} 10$ 세포를 수획하여 멜라닌의 양을 측정한 결과, 멜 라닌의 생성이 농도 의존적으로 저해됨을 확인하였다. 브라질린 을 $1000 \mathrm{ng} / \mathrm{mL}$ 처리할 때 멜라닌의 생성률이 대조군 대비 감소 함을 확인할 수 있었다(Figure 4A). 또한 육안으로 확인한 결과를
수치화하여 확인한 결과, 브라질린을 $1000 \mathrm{ng} / \mathrm{mL}$ 처리할 때 멜 라닌의 생성률이 $37 \%$ 감소하여 대조군 대비 유의성 있게 감소하 였다(Figure 4B). 이 결과는 멜라닌 생성에 필수적인 표지인자의 $\mathrm{mRNA}$ 발현량에 대한 실시간 유전자 중합효소 연쇄반응의 실험 결과와 동일한 경향성을 지니며, 브라질린은 $\mathrm{mRNA}$ 의 발현에 영 향을 미칠 뿐 아니라 멜라닌 생성에서도 일관성있는 미백 효능을 지닌다고 볼 수 있다.

항산화제, 특별히 ascorbic acid는 활성산소종을 제거하는 능력 이 있어 eumelanin 생성과정에서의 중간산물인 DOPA quinone 을 L-DOPA로 환원시켜 멜라닌 합성을 저해하는 중요한 미백소 재로 알려져 있다(Tomita \& Seiji, 1977; Panzella et al., 2018). 브라질린 역시 항산화효과가 있다고 보고되었으며 또한 섬유아세 포에서 항산화효소인 SOD3의 발현을 특이적으로 증가시킨다고 알려져 있다(Shim et al., 2018). 이러한 항산화효능에 의해 브라 질린이 미백에 효과가 있음이 본 실험결과에서도 나타난 것으로 보여진다. 추후 브라질린에 의해 멜라닌형성세포에서의 항산화 효과 및 SOD1, SOD2, SOD3, Catalase와 같은 항산화효소의 발 현양상 등에 대한 추가적인 연구도 진행되어야 할 것으로 사료된 다. 
A

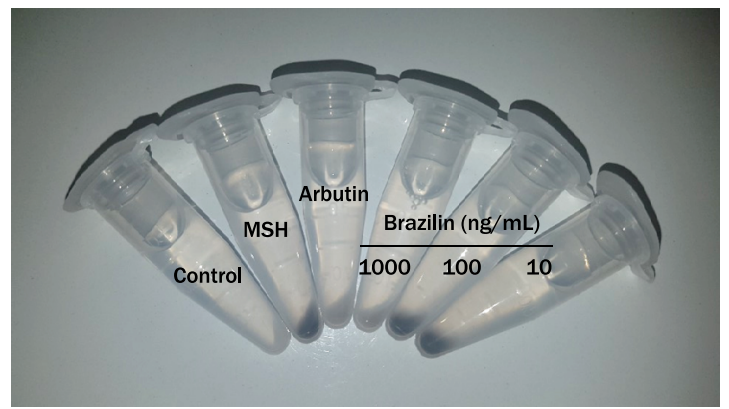

B

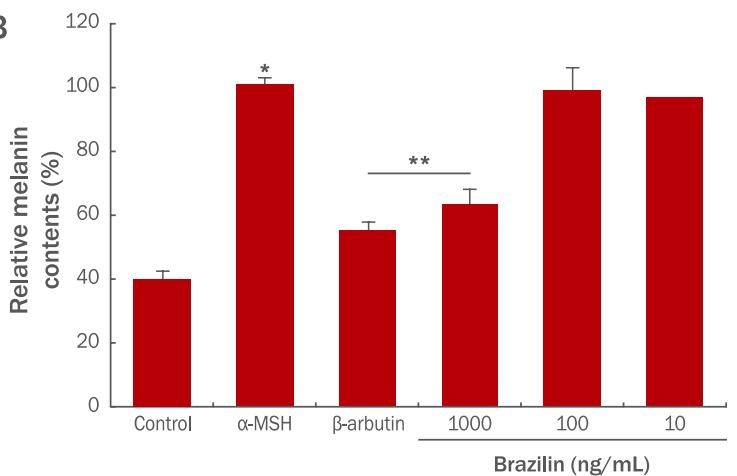

Figure 4. Melanin synthesis inhibition of brazilin on B16F10 cells.

Representative image of B16F10 cells after brazilin treatment (A). The treated cells were lysed with $1 \mathrm{~N} \mathrm{NaOH}$ and the absorbance was measured at $490 \mathrm{~nm}(\mathrm{~B})$. The results are expressed as means \pm standard deviation of data obtained three independent experiments. *means compared to control, ${ }^{* *}$ means compared to $\alpha$-MSH-treated condition $\left({ }^{*},{ }^{* *} p<0.05\right) . \alpha-M S H, \alpha$-melanocyte-stimulating hormone.

\section{Conclusion}

일상생활에서 접하는 자외선은 살균작용, 비타민 D 합성 등 의 유익한 기능이 있으나, 또 다른 측면에서는 주름생성, 탄력저 하, 색소침착, 피부홍반, 염증 등의 증상을 유발하고, 활성산소종 의 연쇄 반응을 통해 노화가 진행된다(Talwar et al., 1995; Kim et al., 2011). 또한 자외선과 같은 환경적 요인에 의한 노화는 성 체 내 존재하는 구성세포의 감소, 혹은 기능저하에 의해 정상적인 기능을 하는 조직으로의 재생, 기능을 하지 못하게 된다(Jones et al., 2011; Kirkwood, 2005).

본 연구를 통해 브라질린을 $\mathrm{B} 16 \mathrm{~F} 10$ 세포에 처리할 적절 한 농도를 확인할 수 있었다. $1000 \mathrm{ng} / \mathrm{mL}$ 의 농도에서는 세포 의 생존율에 영향을 미치지 않음을 Figure 1 에서 확인하였다. Tyrosinase 효소의 활성억제효능 측정결과에서 $100,1000 \mathrm{ng} /$ $\mathrm{mL}$ 농도의 브라질린이 tyrosinase 효소의 활성을 유의성있게 감 소시킬 수 있음을 확인하였다(Figure 2). TRP1, TRP2, TYR과 $M I T F$ 의 유전자 발현 측정에서 브라질린이 $\alpha-\mathrm{MSH}$ 에 의해 증가 된 표지인자 발현을 유의성 있게 감소시키는 결과를 나타내었다 (Figure 3). 추가적으로 브라질린이 B16F10 세포에서 멜라닌의 생성을 감소시킴을 확인하였다(Figure 4). 이러한 결과를 바탕으 로 브라질린이 새로운 미백효능 후보물질로서의 가능성을 보여준 다.

브라질린의 미백 효과를 확인한 결과는 본 연구가 최초로, 추후 피부미용에 실질적으로 응용이 될 수 있고, 피부 노화를 예방할 수 있는 가능성을 제시한 결과라고 사료된다. 추가적으로 브라질 린이 B16F10 세포에서 어떠한 신호전달 기전으로 미백에 영향을 미치는지에 대해 추가연구와 심도있는 임상연구가 필요할 것으로 보인다.

\section{Acknowledgements}

이 논문은 2019학년도 세명대학교 교내학술연구비 지원에 의 해 수행된 연구임.

\section{References}

Bae IK, Min HY, Han AR, Seo EK, Lee SK. Suppression of lipopolysaccharide expression of inducible nitric oxide synthase by brazilin in RAW264.7 macro phage cells. European Journal of Pharmacology, 513: 237-242, 2005.

Baek YS, Ryu YB, Curtis-Long MJ, Ha TJ, Rengasamy R, Yang MS, Park KH. Tyrosinase inhibitory effects of 1,3-diphenylpropanes from Broussonetia kazinoki. Bioorgainc \& Medicinal Chemistry, 17: 35-41, 2009.

Chung JH, Seo JY, Lee MK, Eun HC, Lee JH, Kang S, Fisher GJ, Voorhees JJ. Ultraviolet modulation of human macrophage metalloelastase in human skin in vivo. The Journal of Investigative Dermatology, 119: 507-512, 2002.

Gilchrest BA. A review of skin ageing and its medical therapy. The British Journal of Dermatology, 135: 867-875, 1996.

Han NK, Park CM, Kwon JC, Joung MS, Choi JW. Whitening effect of Fagopyrum tataricum extract. Journal of the Society of Cosmetic Scientists of Korea, 40: 179-186, 2014.

Hwang GS, Kim JY, Chang TS, Jeon SD, So DS, Moon CK. 
Effects of brazilin on the phospholipase A2 activity and changes of intracellular free calcium concentration in rat platelets. Archives of Pharmacal Research, 21: 774$778,1998$.

Hwang HS, Shim JH. Brazilin and Caesalpinia sappan L. extract protect epidermal keratinocytes from oxidative stress by inducing the expression of GPX7. Chinese Journal of Natural Medicines, 16: 203-209, 2018.

Jones DL, Rando TA. Emerging models and paradigms for stem cell ageing. Nature Cell Biology, 13: 506-512, 2011.

Kim HJ, Seo SH, Lee BG, Lee YS. Identification of tyrosinase inhibitors from Glycyrrhiza uralensis. Planta Medica. 71: 785-787, 2005.

Kim J, Lee CW, Kim EK, Lee SJ, Park NH, Kim HS, Kim HK, Char K, Jang YP, Kim JW. Inhibition effect of Gynura procumbens extract on UV-B-induced matrixmetalloproteinase expression in human dermal fibroblasts. Journal of Ethnopharmacology, 137: 427433, 2011.

Kim BY, Park SH, Park BJ, Kim JJ. Whitening effect of Androsace umbellate extract. Journal of the Society of Cosmetic Scientists of Korea, 41: 21-26, 2015.

Kirkwood TB. Understanding the odd science of aging. Cell, 120: 437-447, 2005.

Moon CK, Park KS, Kim SG, Won HS, Chung JH. Brazilin protects cultured rat hepatocytes from BrCCl3-induced toxicity. Drug and Chemical Toxicology, 15: 81-91, 1992.

Panzella L, Ebato A, Napolitano A, Koike K. The late stages of melanogenesis: exploring the chemical facets and the application opportunities. International Journal of Molecular Sciences, 19: 1753, 2018.

Puchtler H, Meloan SN, Waldrop FS, Application of current chemical concepts to metal-hematein and -brazilein stains. Histochemistry, 85:353-364, 1986.

Shim JH. Anti-aging effect of brazilin in UVA-irradiated dermal fibroblasts. Asian Journal of Beauty and Cosmetology, 13: 249-257, 2016

Shim JH. Anti-inflammatory effect of brazilin in RAW264.7 cells. Asian Journal of Beauty and Cosmetology, 17: 107115, 2019.

Talwar HS, Griffiths CE, Fisher GJ, Hamilton TA, Voorhees JJ. Reduced type I and type III procollagens in photodamaged adult human skin. The Journal of Investigative Dermatology, 105: 285-290, 1995.

Tomita Y, Seiji M. Inactivation mechanism of tyrosinase in mouse melanoma. The Journal of Dermatology, 4: 245249, 1977.

Yoon YM, Bae SH, An SK, Choe YB, Ahn KJ, An IS. Effects of ultraviolet radiation on the skin and skin cell signaling pathways. Asian Journal of Beauty and Cosmetology, 11: 417-426, 2013. 


\section{국문초록}

\section{$\mathrm{B} 16 \mathrm{~F} 10$ 세포에서 브라질린의 미백 효능}

심중현

세명대학교 화장품뷰티생명공학부 피부기초과학연구실, 충청북도 제천시, 한국

목적: 본 연구는 브라질린이 B16F10 세포의 미백 효과를 확인하기 위하여 수행되었다. 방법: MSH에 의해 유도된 B16F10 세포의 흑화가 브라질린에 의해 완화되는지 여부를 확인하기 위해서 브라질린의 농도별 세포 생존률, 타이로시나제 활성도 억제, 멜라닌 생성을 유도하는 $\mathrm{mRNA}$ 의 발현 양상, 멜라닌 단백질의 생성 정도를 확인하였다. 결과: 브라질린의 미백 효과를 확인하기 위하여 타이로시나제 활성도를 측정한 결과, $1000,100 \mathrm{ng} / \mathrm{mL}$ 의 브라질린을 처리한 조건에서 각각 $60,23 \%$ 의 타이로시나제 활성도를 억 제하는 효과를 보였다. 또한 TRP1/TRP2/TYR/MITF 의 유전자 발현을 확인한 결과, $\mathrm{MSH}$ 에 의해 증가한 유전자의 발현이 브라질 린에 의해 각각 $59,47,65,70 \%$ 감소하였다. B16F10 세포의 멜라닌생성에 브라질린이 미치는 영향을 확인한 결과, $1000 \mathrm{ng} / \mathrm{mL}$ 의 브라질린을 처리하였을 때 $37 \%$ 의 멜라닌형성 억제 효능을 보임을 확인할 수 있었다. 따라서 본 연구자는 브라질린의 미백 효능을 확인하였다. 결론: 본 연구결과를 통하여 브라질린의 미백 효능을 확인하였고, 향후 브라질린이 화장품 및 건강식품과 의약품의 개 발에 응용될 수 있는 소재로서의 가능성을 확인하기 위해 추가적인 기전연구가 필요할 것으로 생각된다.

핵심어: 브라질린, 미백, 멜라닌, TYR, MITF

이 논문은 2019학년도 세명대학교 교내학술연구비 지원에 의해 수행된 연구임.

\section{참고문헌}

김보연, 박성하, 박병준, 김진준. 봄맞이 추출물의 미백 효능 연구. 대한화장품학회지, 41: 21-26, 2015.

심중현. 자외선 조사에 의해 노화된 섬유아세포에서 브라질린의 항노화 효능. 아시안뷰티화장품학술지, 13: 249-257, 2016.

심중현. 브라질린의 RAW264.7 세포에서의 항염효과. 아시안뷰티화장품학술지, 17: 107-115, 2019.

윤영민, 배승희, 안성관, 최용범, 안규중, 안인숙. 자외선(Ultraviolet)이 피부 및 피부세포 내 신호전달체계에 미치는 영

향. 아시안뷰티화장품학술지, 11: 417-426, 2013.

한나경, 박창민, 권주찬, 정민석, 최종완. 쓴메밀 추출물의 미백 개선 효과. 대한화장품학회지, 40: 179-186, 2014. 


\section{中文摘要}

\section{巴西木素 (Brazilin) 对B16F10细胞的美白作用}

沁重鉉

世明大学化妆品 美容生命工学科 皮肤基础科学研究室, 忠清北道提川市, 韩国

目的：这项研究旨在鉴定巴西木素对B16F10细胞系的增白作用。方法: 测量B16F10细胞的细胞活力, mRNA表 达, 酪氨酸酶活性抑制测定和黑色素含量测定。此外, 阐明了巴西木素对酪氨酸酶相关蛋白1 (TYRP1)/TYRP2/ 酪氨酸酶 (TYR)/小眼症相关转录因子 (MITF) mRNA表达和黑色素生成的影响。结果：实时荧光定量RT-PCR显 示, 与经MSH处理的B16F10细胞相比, 巴西木素降低了TYRP $1 / T Y R P 2 / T Y R / M I T F$ 和黑色素生成的mRNA水平。 酪氨酸酶活性抑制试验表明, 巴西林降低了B16F10细胞中黑色素的产生。结论: 这些数据表明, 巴西木素提高 了B16F10细胞的美白效果, 因此巴西木素是美白皮肤的有效成分。基于这些结果的未来研究可以确定巴西木素 在化妆品, 保健, 食品或药物中的潜在用途。

关键词: 巴西木素, 美白, 黑色素, TYR, MITF 